\title{
Influence of SDHI Seed Treatment on the Physiological Conditions of Spring Barley Seedlings under Drought Stress
}

\author{
Dominika Radzikowska ${ }^{1, *(0)}$, Monika Grzanka ${ }^{1}$, Przemysław Łukasz Kowalczewski ${ }^{2}$, \\ Romana Głowicka-Wołoszyn ${ }^{3}{ }^{\circledR}$, Andrzej Blecharczyk ${ }^{1}$, Marcin Nowicki ${ }^{4}{ }^{\circledR}$ and \\ Zuzanna Sawinska ${ }^{1}$ (D) \\ 1 Department of Agronomy, Poznań University of Life Sciences, 11 Dojazd St., 60-632 Poznań, Poland; \\ monika.grzanka@up.poznan.pl (M.G.); andrzej.blecharczyk@up.poznan.pl (A.B.); \\ zuzanna.sawinska@up.poznan.pl (Z.S.) \\ 2 Institute of Food Technology of Plant Origin, Poznań University of Life Sciences, 31 Wojska Polskiego St., \\ 60-624 Poznań, Poland; przemyslaw.kowalczewski@up.poznan.pl \\ 3 Department of Finance and Accounting, Poznań University of Life Sciences, 28 Wojska Polskiego St., \\ 60-637 Poznań, Poland; roma@up.poznan.pl \\ 4 Department of Entomology and Plant Pathology, Institute of Agriculture, University of Tennessee, 363 Plant \\ Biotechnology Building, 2505 EJ Chapman Drive, Knoxville, TN 37996-4560, USA; mnowicki@utk.edu \\ * Correspondence: dominika.radzikowska@up.poznan.pl
}

Received: 28 April 2020; Accepted: 18 May 2020; Published: 19 May 2020

\begin{abstract}
Seed treatments help reduce the pathogen load and thus improve the condition of plants from their earliest developmental stages, but they can have impacts beyond their basic fungicide protection role. In this study, we investigated how seven spring barley seed treatments affected the plants' physiological state. The tested seed treatments differed significantly in their impacts on the vigor parameters of barley seeds and on the physiological state of seedlings under drought stress and after regeneration. Seed treatments based on substances from the succinate-dehydrogenase-inhibitors (SDHI) group did not cause inhibition of seedling growth and also display by the highest vigor index values. Using the analysis of photosynthesis-related parameters, we showed that seed treatments from the SDHI group provided a superior tolerance of the imposed drought in spring barley than other treatments. In addition to protection against abiotic stress, SDHI treatments also rendered a higher efficiency of photochemical reactions in the treated plants.
\end{abstract}

Keywords: abiotic stress; chlorophyll fluorescence; fluorescence; Hordeum vulgare L.; photosynthesis; succinate-dehydrogenase-inhibitor

\section{Introduction}

Both seeds and soil can be a source of pathogens potentially weakening the plant development, and consequently reducing the quantity and quality of the crop [1]. Seed treatment helps reduce the pathogen load and thus improves the condition of plants from their earliest developmental stages [2-5]. The beginning of the use of fungicides, especially seed treatments, dates back to 1600, when copper sulphate $\left(\mathrm{CuSO}_{4}\right)$ was used for the first time in a very high concentration to protect wheat from the common bunt fungus [6]. Methionine demethylation inhibitors affecting sterol biosynthesis in fungi (especially triazoles, imidazoles, and pyrimidines) are the most important group of systemic fungicides currently used to treat seeds [7]. Förster et al. [8] noted a strong growth inhibition of barley root, shoot, and coleoptile after treating the seeds with triadimefon and triadimenol. A delay in the extension of the primary leaf after seed treatment with substances from the triazole group has been described in many 
crops $[9,10]$. Reduction of the coleoptile length, primary leaves, and internode length due to the use of triadimenol and triticonazole as a treatments of wheat seed was also well documented $[3,11,12]$. It was thus shown that seed treatments can have a number of impacts beyond their basic fungicide protection role. Carboxamide fungicides (succinate-dehydrogenase-inhibitors; SDHIs) act on the pathogens by inhibiting succinate dehydrogenase in the mitochondrial respiration. The site of SDHI action is the succinate dehydrogenase complex in the respiratory chain (complex II), at the ubiquinone binding site (SQR). As a result of the electron transport interference, mitochondrial respiration is inhibited [13-15]. The first generation of SDHIs dates to the end of the 1960s. These compounds were mainly used for controlling plant diseases caused by Basidiomycetes [16]. The currently used second generation of SDHIs exhibit a broad spectrum of activity against pathogenic fungi for many crop species $[17,18]$.

Carboxamide fungicides' (SDHIs) biological activity has been assessed in this study. Those agents are included in formulations blocking the succinate dehydrogenase (SDH) activity. Active substances classified in the SDHI group are derived from various ranges of chemistry and have protective, translaminar, or systemic activity. Sedaxane, as the literature indicates, is a broad-spectrum substance that controls seed-borne pathogens such as Ustilago nuda, Tilletia caries, Microsochium nivale, and Pyrenofora graminea, as well as soil-borne fungi: Rizoctonia solani, Rizoctonia cerealis, and Typhula incarnata. The discovery of this substance was the result of an intensive chemical synthesis and a biological research program that included hundreds of carboxamide analogues. Sedaxane was chosen by Syngenta for use only as a seed treatment, because it combines the optimal physicochemical properties, a wide spectrum of activity and renders an excellent plant tolerance. It specifically inhibits the enzyme SDH, which catalyzes an important stage in the trichloroacetic acid cycle and the respiratory chain of pathogens [19-21]. According to Ajigboye et al. [22], the fact that Sedaxane inhibits the SDH complex II in fungal mitochondria may suggest that it exerts a similar effects on the plant mitochondrial complex as well.

Fluxapyroxad, a second generation SDHI fungicide, is an active substance developed by BASF in 2012 to control a wide spectrum of plant fungal pathogens. The active substance are two acids: 3-(difluoromethyl)-1-methyl-1H-pyrazole-4-carboxylic (C-1) and 3-(difluoromethyl)-1H-pyrazole4-carboxylic (C-2) and 3-(difluoromethyl)-1-methyl-1H-pyrazole-4-carboxamide (C-7) [23]. One of the formulas based on this substance is BAS $70005 \mathrm{~F}$, a seed treatment solution that protects cereals from seed-borne and soil-borne pathogens such as Ustilago spp., Pyrenophora spp., M. nivale, and Fusarium spp. and against early leaf infections especially in barley cultivation caused by Puccinia hordei, P. teres, Rhynchosporium secalis, and Ramularia collo-cygni [24].

An emerging limiting factor in plant growth beyond the pathogens is the abiotic stress caused by water deficit and extremely high temperatures at low humidity, leading to drought stress [25-27]. Due to the changing climatic conditions, tolerance to abiotic stress is becoming one a particularly desirable characteristic in plant crops. Analyses of gene expression and measurements of gas exchange and fluorescence of chlorophyll indicated that fungicides from the SDHI group increase the photosynthesis and photosystem II (PSII) efficiency in plants under drought stress [22].

Photosynthesis is unquestionably the most important physiological process carried-out by plants. It is the basic factor underlying the biomass creation, and thus the production of the final crop [28-30]. Strong drought often associated with elevated temperature and high light intensity limits $\mathrm{CO}_{2}$ assimilation and causes increased photoexcitation energy in PSII. This in turn disturbs the balance between the supply of assimilation force produced in photochemical reactions (ATP and NADPH) and reduces the related demand of the Calvin-Benson cycle. The outcome forces the plant to various processes of scattering the excess energy absorbed by chlorophyll. One of such processes is an increased fluorescence. Chlorophyll fluorescence is a measure of the energy of absorbed light quanta that has not been used in photosynthesis and has not been emitted as heat [31-33]. Fluorescence intensity, therefore, measures how strongly the processes related to the functioning of PSII are disturbed. As a physiological parameter, it allows to determine whether the plant has become stressed and to assess the time it needs for complete regeneration. 
Abiotic stress is considered to be the main limitation of crop failure worldwide, which can potentially reduce the average yield of most field crops by more than 50\% [34]. Variations in environmental conditions, such as photoperiod, nutrient status and solar radiation, can affect plant growth and development [35], however drought-related stress is one of the most important abiotic factors affecting the reduction of seed yield and biomass in global agriculture. In the face of climate change, an increase in the frequency of insufficient precipitation and the resulting dryness in many parts of the world is forecast [36,37], therefore, improving drought tolerance was an important goal of crop improvement programs.

It is well known that water deficiency can disturb a wide range of basic plant physiological and metabolic reactions that are involved in regulating crop growth and yield. In addition, drought stress can lead to increased production of reactive oxygen species (ROS), including hydrogen peroxide, hydroxyl radical and superoxide anion [38]. Generated ROS can cause the oxidation of photosynthetic pigment particles, membrane lipids, proteins and nucleic acids, and thus interfere with the normal functioning of the cell. To alleviate the destructive effects of ROS, plants have developed several adaptations and protective mechanisms that include stimulation of effective enzymatic [superoxide dismutase (SOD), catalase (CAT), peroxidase (POD) and ascorbate peroxidase (APX)] and nonenzymatic (phenolic acids, carotenoids, flavonoids, ascorbic acid, proline, etc.) pathways of antioxidant defense [39,40].

Barley (Hordeum vulgare L.) is a crop often grown in dry and semi-dry areas. Water deficit in these areas and improper distribution of precipitation reduce the germination and growth of barley [41]. Barley is one of the most important cereal crops in many developing countries, where it is often subject to extreme drought stress, which significantly affects its yield [42]. It is grown in a wider environmental range than any other cereals with an unfavorable climate. Under these conditions, barley encounters drought stress during seed germination and early stages of growth. These stages are most exposed to drought stress and pose a challenge in barley production. For instance, in the studies described by Nosalewicz et al. [43] it has been shown that by exposing barley to drought-related stress during reproductive stages, it reduced the ratio of shoots:roots and the number of thick roots in the F1 generation.

Naturally, drought stress affects the interaction of the plant with the pathogen when both stress occurs simultaneously, therefore, the aim of this study was to assess how seven seed treatments of spring barley under drought stress conditions affect the plant physiological state. Those treatments contained active substances from the fungicide groups of phenylpyrroles, carboxamides, and triazoles.

\section{Materials and Methods}

\subsection{Plant Material and Growing Conditions}

As the plant model in our study, we used spring barley (Hordeum vulgare L. conv. distichon) cultivar 'Penguin' purchased from Danko Plant Breeding (Choryń, Poland). Plants were grown for 30 days in potted cultures in a greenhouse $\left(60 \%\right.$ to $80 \%$ relative humidity, 20 to $25^{\circ} \mathrm{C}, 16 \mathrm{~h}$ day $/ 8 \mathrm{~h}$ night). Natural sunlight was supplemented with sodium lamps light (HPS) with a capacity $400 \mathrm{~W}$ (Elektro-Valo Oy Netafim, Avi:13473/, Uusikaupunki, Finland). Ten barley seeds of equal size were sown in triplicate, in each $1.0 \mathrm{dm}^{3}$ pot filled with the same amount of soil substrate (universal substrate, pH 5.5). Seven various seed treatments were used before sowing (Table 1). The control group consisted of the untreated seeds.

Soil moisture was maintained at a constant level of $12 \%$ and regularly watered $\left(100 \mathrm{~mL} \mathrm{H}_{2} \mathrm{O} / \mathrm{vase}\right.$ every $48 \mathrm{~h}$ ) and was monitored daily with a probe (ThetaProbe, Eijkelkamp, The Netherlands). Drought stress was imposed in the second leaf phase, by stop the watering. A 10 days after drought imposition, soil moisture reached $4 \%$ to $5 \% v / v$, and became hardly available to plants. All the leaves clearly lost their vigor. At that time, the physiological state of plants was determined in both the watered control and the drought stressed plants. 
Table 1. Active substances and trade names of seed treatments used in experiment.

\begin{tabular}{clc}
\hline Treatment ID & \multicolumn{1}{c}{ Active Substances of Seed Treatments } & Trade Name of Treatments \\
\hline 1 & Control - untreated & Maxim ${ }^{\circledR}$ 025 FS/ \\
2 & Fludioxonil $25 \mathrm{~g} / \mathrm{L}$ & $\begin{array}{c}\text { Celest }{ }^{\circledR} 025 \mathrm{FS} \\
\text { Vibrance }{ }^{\circledR} \text { Duo } /\end{array}$ \\
3 & Fludioxonil $25 \mathrm{~g} / \mathrm{L}+$ sedaxane $25 \mathrm{~g} / \mathrm{L}$ & Maxim ${ }^{\circledR}$ Power \\
4 & Fludioxonil $25 \mathrm{~g} / \mathrm{L}+$ sedaxane $25 \mathrm{~g} / \mathrm{L}+$ & Vibrance ${ }^{\circledR}$ Star \\
5 & triticonazole $20 \mathrm{~g} / \mathrm{L}$ & Triter 050 FS \\
6 & Triticonazole $50 \mathrm{~g} / \mathrm{L}$ & Redigo ${ }^{\circledR}$ Pro $170 \mathrm{FS}$ \\
7 & Prothioconazole $150 \mathrm{~g} / \mathrm{L}+$ tebuconazole $20 \mathrm{~g} / \mathrm{L}$ & Kinto ${ }^{\circledR}$ Plus \\
8 & Fludioxonil $33.3 \mathrm{~g} / \mathrm{L}+$ fluxapyroxad $33.3 \mathrm{~g} / \mathrm{L}+$ & Madron $50 \mathrm{FS}$ \\
\hline
\end{tabular}

Before the measurements, the plants were placed in in the dark for $9 \mathrm{~h}$ to silence photosynthesis. The entire measurement was carried out in a phytotron at a constant air temperature of $25{ }^{\circ} \mathrm{C}$. After measurements, the plants were transferred back to the greenhouse and the watering regime was applied again to reach soil moisture of $12 \%$ and watered as mentioned previously. After 7 days, as the plants regained the turgor, a second measurement of the physiological state of the plants was carried out. Both measurements of the physiological state of plants (during drought stress and after plant regeneration) were carried out in an analogous manner. The same order of measurements was maintained. Drought-stressed plants and watered plants were measured alternately. For the measurements of the photosynthesis rate and chlorophyll fluorescence, the youngest fully developed leaf was used.

\subsection{Assessment of Barley Seeds Quality}

The assessment of seed sowing quality was carried out in accordance with the protocols described in the Main Inspectorate of Plant Health and Seed Inspection of Poland and the International Seed Testing Association [44,45], which include: germination energy, germination capacity, and vigor index. In addition, the root length was determined. The seedling growth test was performed on a roll test basis, on a 25-grain sample, in four replications. Each roll consisted of 3 layers of wetted filter paper $30 \mathrm{~cm}$ $\times 45 \mathrm{~cm}$ (quality paper type $\mathrm{R}$ with a retention time of $30 \mathrm{~s}$ ). The rolls were placed in a thermostatic cabinet 'ST 5+' (Pol-Eko-Aparatura, Wodzisław Ślaski, Poland) at a temperature of $19^{\circ} \mathrm{C}$ and the barley germination energy was determined after 5 days, and germination capacity after 7 days. After this period, the length of normal seedlings was measured.

The vigor index was calculated according to the following formula:

Vigor index $(\mathrm{VI})=[$ seedling length $(\mathrm{cm}) \times$ germination $(\%)]$.

\subsection{Physiological State of Plants}

\subsubsection{Plant Photosynthesis}

Plant photosynthesis intensity was assessed based on rate of $\mathrm{CO}_{2}$ exchange $-\mathrm{A}(\mathrm{v})$, transpiration rate $-\mathrm{E}\left(\mu \mathrm{mol} \times \mathrm{m}^{-2} \times \mathrm{s}^{-1}\right)$, sub-stomatal $\mathrm{CO}_{2}-\mathrm{Ci}\left(\mu \mathrm{mol} \times \mathrm{mol}^{-1}\right)$ and stomatal conductance - Gs $\left(\mathrm{mol} \times \mathrm{m}^{-2} \times \mathrm{s}^{-1}\right)$ in the leaf chamber of single leaves. The measurements were taken for the first young fully mature healthy leaf using a portable photosynthesis system (LCpro-SD, ADC BioScientific Ltd., Hoddesdon, UK) with a narrow leaf chamber (area: $5.8 \mathrm{~cm}^{2}$ ). Photosynthesis measurements were carried out in triplicate for each factorial combination. The $\mathrm{CO}_{2}$ concentration (Reference $\mathrm{CO}_{2}$ ) in the leaf chamber was kept at $360 \mathrm{vpm}$, leaf chamber temperature was (Tch) at $25 \pm 1{ }^{\circ} \mathrm{C}$, the flow rate of air (u) was kept at $200 \mu \mathrm{mol} \times \mathrm{s}^{-1}$, and ambient $\mathrm{H}_{2} \mathrm{O}$ concentration (Reference $\mathrm{H}_{2} \mathrm{O}$ ). Photosynthetically 
active radiation (PAR) was kept at $400 \mu \mathrm{mol} \times \mathrm{m}^{-2} \times \mathrm{s}^{-1}$, adjusted automatically by a red-blue light-emitting diode light source (LCP Narrow Lamp, ADC BioScientific Ltd.).

\subsubsection{Plant Chlorophyll Fluorescence}

Chlorophyll fluorescence was measured at the same leaf and at the same light intensity as photosynthesis $\left(\mathrm{PAR}=400 \mu \mathrm{mol} \times \mathrm{m}^{-2} \times \mathrm{s}^{-1}\right.$ ), with Multi-Mode Chlorophyll Fluorometer (OS5p, Opti-Sciences, Inc., Hudson, NY, USA) with a PAR Clip that allows the measurement of PAR and leaf temperature. A kinetic test mode that combines the measurements under the light conditions and the measurements after dark adaptation was selected. Fluorescence measurements were carried out in six replicates for each combination. The fluorometer settings protocol followed our previous study [46]: Modulation Source: Red, Modulation Intensity: 29, Detector Gain: 06, Saturation Flash Intensity: 30, Flash Count: 001, Flash Rate: 255 (sec). The following parameters were measured: $\mathrm{F}_{0}$-minimum fluorescence, $\mathrm{F}_{\mathrm{m}}$ - maximum fluorescence, $\mathrm{Y}$-Quantum Yield of Photosynthetic Energy, ETR-Electron Transport Rate.

\subsection{Statistical Analysis}

The effect of two factors (presence of drought stress and type of seed treatment) on the physiological state of plants was examined using two-way ANOVA with replicates. The bidirectional ANOVA model for factor interactions was as follows:

$$
y_{i j}=\mu+\alpha_{i}+\beta_{j}+(\alpha \beta)_{i j}+e_{i j}
$$

where $y_{i j}$-estimated value of variables (photosynthesis parameters) in the presence or absence of drought stress $(i=1,2)$ and using the chosen type of treatment $(j=1,2, \ldots, 8), \mu-$ overall average, $a_{i}$-the effect of the occurrence or absence of drought stress, $\beta_{j}$-the effect of $j$-type treatment, $(\alpha \beta)_{i j}$-effect of interaction of drought stress and treatment and $e_{i j}$ - random error.

In the case of rejection of null hypotheses about the lack of influence of the factors analyzed or their interactions, Tukey's procedure was used for multiple comparisons.

In order to determine the mutual relations between the analyzed parameters of the physiological state of plants (parameters $\mathrm{Ci} ; \mathrm{Gs} ; \mathrm{A} ; \mathrm{E} ; \mathrm{Y} ; \mathrm{F}_{0} ; \mathrm{F}_{\mathrm{m}} ; \mathrm{ETR}$ ), the principal components analysis was carried out and biplots were used to illustrate the results obtained [47]. The linear combinations of the active variables listed above maximizing the amount of total variance explained were used as the main axes (main components) of the biplots. The vectors coming from the center of gravity of the set of points represent selected photosynthesis parameters. Two biplots were presented in the study. On both biplots, the points represent all seed treatment combinations (eight variants) and the presence or absence of drought stress (control/drought), a total of 16 combinations, with the first biplot presenting the results obtained during drought and the second during regeneration.

\section{Results}

\subsection{Effect of the Seed Treatments on Germination Energy and Germination Capacity}

Seed germination energy differed significantly depending on the seed treatment used (Table 2). Significant differences were also noted for germination capacity. Seeds treated with prothioconazole plus tebuconazole showed the lowest germination energy and germination capacity as compared to other analyzed seed treatments. The seed treatments used also significantly changed the values of the calculated vigor index. Barley seeds treated with treatments containing sedaxane (treatments No. 3,4, 7 and 8) had the highest values of the vigor index. The lowest value of this parameter was noted for variant 6 , in which prothioconazole and tebuconazole were used. 
Table 2. Impact of applied treatments on germination energy, germination capacity, vigor index, root and shoot length of spring barley seeds.

\begin{tabular}{|c|c|c|c|c|c|}
\hline Treatment & Germination Energy & Germination Capacity & Vigor Index & Root Length & Shoot Length \\
\hline 1. Control - untreated & $92.0 \pm 0.1^{\mathrm{a}}$ & $92.7 \pm 1.2^{\mathrm{bc}}$ & $5263 \pm 544.8^{\mathrm{a}}$ & $60.4 \pm 3.5^{\mathrm{ab}}$ & $57.2 \pm 6.4^{\mathrm{ab}}$ \\
\hline 2. Fludioxonil & $92.0 \pm 0.1^{\mathrm{a}}$ & $95.3 \pm 2.3^{a b c}$ & $4796 \pm 154.5^{\mathrm{a}}$ & $51.0 \pm 3.8^{b}$ & $52.1 \pm 2.2^{\mathrm{ab}}$ \\
\hline 3. Fludioxonil + sedaxane & $88.0 \pm 4.0^{\mathrm{a}}$ & $95.3 \pm 2.3^{\mathrm{abc}}$ & $5832 \pm 480.8^{\mathrm{a}}$ & $59.6 \pm 6.9^{\mathrm{ab}}$ & $66.3 \pm 5.0^{\mathrm{a}}$ \\
\hline 4. Fludioxonil + sedaxane + triticonazole & $93.3 \pm 4.6^{\mathrm{a}}$ & $94.0 \pm 3.5^{\mathrm{abc}}$ & $5497 \pm 436.4^{\mathrm{a}}$ & $70.1 \pm 8.7^{\mathrm{a}}$ & $58.9 \pm 4.1^{\mathrm{ab}}$ \\
\hline 5. Triticonazole & $92.0 \pm 6.9^{a}$ & $97.3 \pm 2.3^{\mathrm{a}}$ & $4211 \pm 496.5^{\mathrm{ab}}$ & $56.4 \pm 2.7^{\mathrm{ab}}$ & $44.8 \pm 2.5^{\mathrm{b}}$ \\
\hline 6. Prothioconazole + tebuconazole & $80.0 \pm 4.0^{\mathrm{b}}$ & $91.3 \pm 2.3^{c}$ & $3192 \pm 165.4^{\mathrm{b}}$ & $57.4 \pm 4.4^{\mathrm{ab}}$ & $40.0 \pm 3.2^{\mathrm{b}}$ \\
\hline 7. Fludioxonil + fluxapyroxad + triticonazole & $92.0 \pm 6.0^{\mathrm{a}}$ & $94.7 \pm 4.2^{\mathrm{abc}}$ & $5005 \pm 652.2^{\mathrm{a}}$ & $67.2 \pm 1.4^{\mathrm{a}}$ & $54.2 \pm 15.97^{\mathrm{ab}}$ \\
\hline 8. Fludioxonil & $93.3 \pm 4.6^{\mathrm{a}}$ & $96.0 \pm 2.0^{\mathrm{ab}}$ & $5285 \pm 897.1^{\mathrm{a}}$ & $56.9 \pm 7.8^{\mathrm{ab}}$ & $56.5 \pm 8.1^{\mathrm{ab}}$ \\
\hline LSD & 7.3 & 4.6 & 1138 & 15.1 & 20.7 \\
\hline
\end{tabular}

Different letters indicate statistically different mean values $p<0.05$. 
Analysis of the average length of barley sprouts showed that treatments containing prothioconazole with tebuconazole most strongly reduced the length of the seedling among all the analyzed preparations. The longest shoot length, $66.3 \pm 5.0 \mathrm{~mm}$ long in average, were observed in treatment No. 3 (Table 2). The root length test showed that sprouts from the seed treatment No. 4 containing fludioxonil + sedaxane + triticonazole were the longest $(70.1 \pm 8.7 \mathrm{~mm})$, whereas they were the shortest $(51.0 \pm$ $3.8 \mathrm{~mm}$ ) for combination No. 2, based on fludioxonil.

\subsection{Effect of the Seed Treatments on the Physiological State of Plants During Drought Stress}

A significant impact of the applied seed treatments on the efficiency of photosynthesis measured during drought stress was recorded. The use of any seed treatment significantly increased $\mathrm{CO}_{2}$ assimilation in plants growing under drought stress compared to the untreated seeds. Only treatment No. 8 resulted in no increase of $\mathrm{CO}_{2}$ assimilation under well-watered conditions. The highest levels of $\mathrm{CO}_{2}$ assimilation under well-watered conditions were found for plants with seeds subjected to treatments No. 4 and 7, for which the increase of $\mathrm{CO}_{2}$ assimilation in relation to untreated control was: $83 \%$ and $76 \%$, respectively, whereas in relation to plants growing under drought $-41 \%$ and $38 \%$. Photosynthesis measurement under drought stress showed the highest $\mathrm{CO}_{2}$ assimilation in plants treated with treatment No. 3 (Table 3).

Significant impact of the seed treatments used on the level of transpiration rate (E) was also recorded. The most intense transpiration under well-watered conditions was observed for plants with seeds subjected to treatment No. 4 and it exceeded the untreated control by $63 \%$, whereas under drought stress by $13 \%$. Under drought, the highest level of transpiration was observed in plants treated with seeds subjected to No. 6 (exceeding the untreated control by 26\%), and the lowest to No. 7 (lower than the untreated control by $17 \%$ ) (Table 4 ).

The highest values of stomatal conductance (Gs) under well-watered conditions were observed in plants with seeds subjected to treatments No. 3, 4, and 7, exceeding the untreated control by $70 \%, 67 \%$, and $63 \%$, respectively. Contrastingly, during drought stress, the Gs parameter values indicated smaller differences among the treatments used, and the highest level of Gs was observed in plants with seeds subjected to treatment No. 4 (higher than untreated control by 21\%) (Table 5).

Similar results were obtained for the measurements of sub-stomatal conductance of $\mathrm{CO}_{2}(\mathrm{Ci})$. Under well-watered conditions, the highest value of $\mathrm{Ci}$ was recorded for plants with seeds subjected to treatment No. 4 ( $20 \%$ higher than the untreated control). In contrast, the highest values of Ci under drought were recorded for plants with seeds subjected to treatments No. 3, 4, and 6 (higher than the untreated control by $15 \%, 15 \%$, and $13 \%$, respectively) (Table 6).

Based on the analysis of chlorophyll fluorescence, we found a significant effect of the applied seed treatments on both parameters measured after plants adaptation to darkness: minimum fluorescence $\left(\mathrm{F}_{0}\right)$ and maximum fluorescence $\left(\mathrm{F}_{\mathrm{m}}\right)$, and both parameters measured under luminescence: quantum yield of photosynthetic energy $(\mathrm{Y})$ and electron transport rate (ETR) (Figure 1).

The highest $\mathrm{F}_{0}$ values (Figure $1 \mathrm{~A}$ ), both during measurement under drought and under well-watered conditions, were found for plants with seeds subjected to no treatment. High values of the $\mathrm{F}_{0}$ parameter were also noted in plants with seeds subjected to seed treatments No. 2, 6, and 8 under well-watered conditions, and No. 6 and 8 under drought. The lowest values of the $F_{0}$ parameter were recorded in plants under drought with seeds subjected to treatments No. 3, 4 and 7. Marginally larger differences between the analyzed seed treatments were noted in the case of maximum fluorescence $\left(F_{m}\right)$ (Figure 1C). The highest values of this parameter under drought were recorded for plants with seeds subjected to treatment No. 3, whereas the lowest-for the untreated plants under drought stress with their $\mathrm{F}_{\mathrm{m}} 34 \%$ lower than the value for plants with seeds subjected to treatment No. 3 . The highest values of ETR (Figure 1E) and Y (Figure 1G) parameters were found for plants under well-watered conditions, with seeds subjected to treatment No. 7. The increase in the value of both parameters in relation to untreated and unstressed plants was $21 \%$. Under drought, the highest values of ETR and Y 
parameters were recorded for plants with seeds subjected to treatment No. 4, and the increase of their value in relation to untreated plants, under drought stress, was $14 \%$.

During drought stress

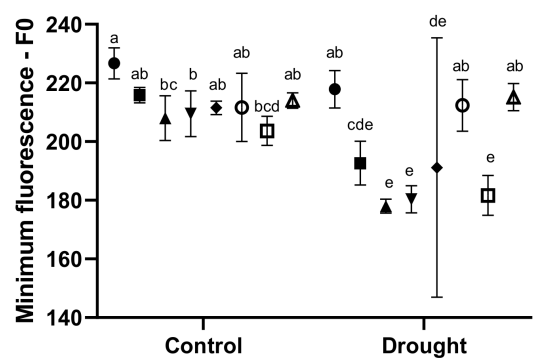

A

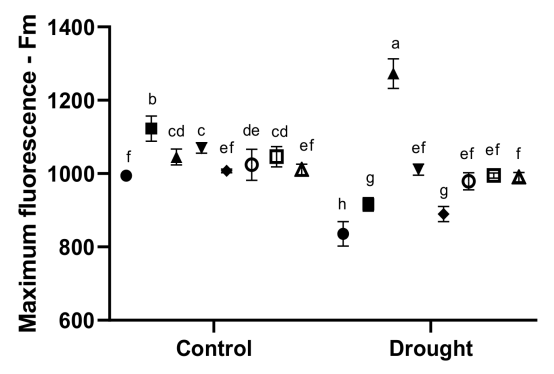

C

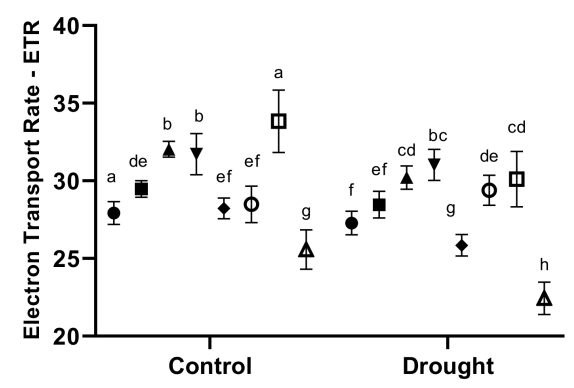

E

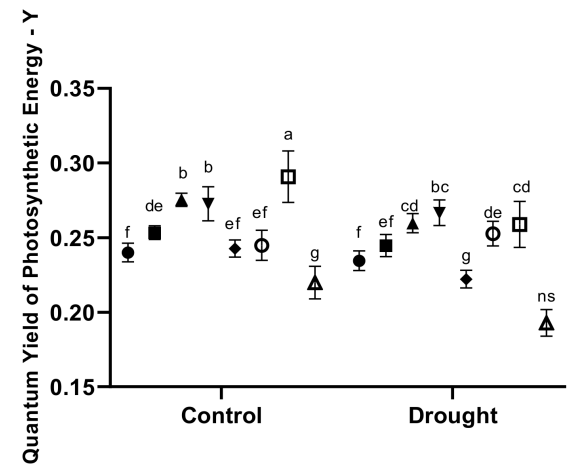

G
After regeneration

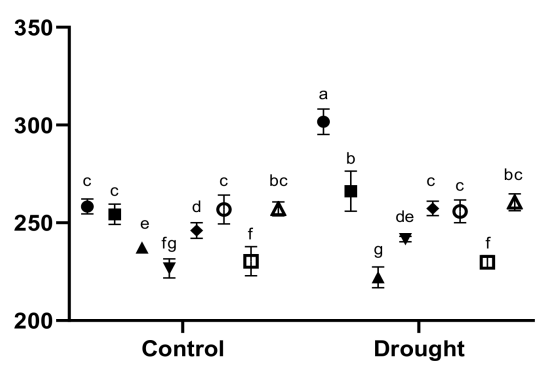

B

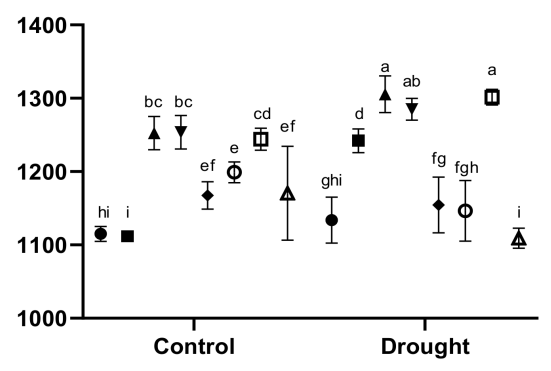

D

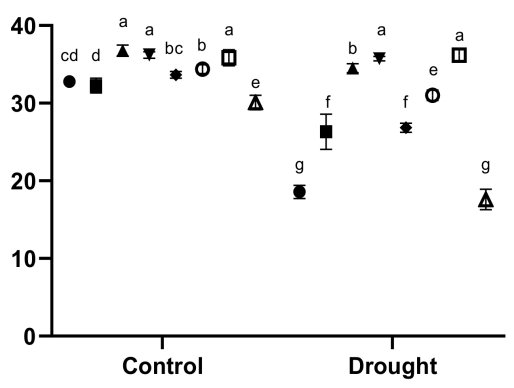

$\mathbf{F}$

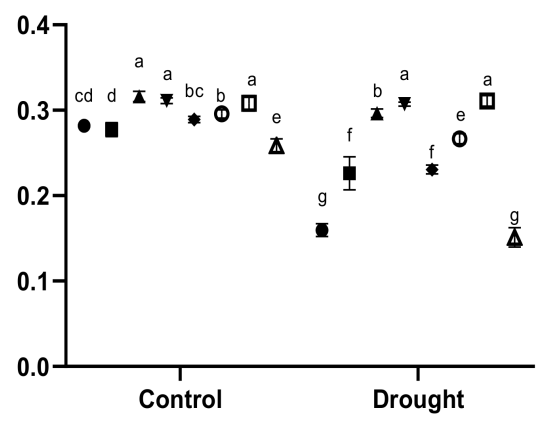

$\mathbf{H}$

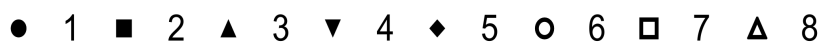

Figure 1. Parameters of chlorophyll fluorescence (non-nominated units): left column graphs imaging measurements during drought stress and right column graphs imaging measurements after regeneration. Letters a-i indicate statistically different mean values $(p<0.001)$. 
Table 3. The influence of the seed treatment and drought stress on photosynthesis rate $\left(\mathrm{CO}_{2}\right.$ assimilation $)-\mathrm{A}\left(\mathrm{mmol} \times \mathrm{m}^{-2} \times \mathrm{s}^{-1}\right)$ during drought stress and after regeneration.

\begin{tabular}{|c|c|c|c|c|}
\hline \multirow{2}{*}{ Treatment } & \multicolumn{2}{|c|}{ During Drought Stress } & \multicolumn{2}{|c|}{ After Regeneration } \\
\hline & Control & Drought & Control & Drought \\
\hline 1. Control - untreated & $6.440 \pm 0.290^{j}$ & $6.767 \pm 0.416^{\mathrm{ij}}$ & $9.627 \pm 0.340^{h}$ & $10.553 \pm 0.125^{g}$ \\
\hline 2. Fludioxonil & $8.930 \pm 0.061^{\mathrm{d}}$ & $8.643 \pm 0.174$ def & $8.005 \pm 0.065^{\mathrm{i}}$ & $12.180 \pm 0.100^{\mathrm{cd}}$ \\
\hline 3. Fludioxonil + sedaxane & $10.580 \pm 0.370^{b}$ & $8.803 \pm 0.280^{\mathrm{de}}$ & $13.797 \pm 0.237^{\mathrm{a}}$ & $13.387 \pm 0.270^{\mathrm{b}}$ \\
\hline 4. Fludioxonil + sedaxane + triticonazole & $11.760 \pm 0.340^{\mathrm{a}}$ & $8.350 \pm 0.165$ efg & $13.077 \pm 0.112^{b}$ & $13.807 \pm 0.329^{a}$ \\
\hline 5. Triticonazole & $7.210 \pm 0.288 \mathrm{hi}$ & $8.060 \pm 0.017^{g}$ & $9.970 \pm 0.05^{\mathrm{h}}$ & $11.013 \pm 0.012^{\mathrm{f}}$ \\
\hline 6. Prothioconazole + tebuconazole & $9.390 \pm 0.250^{c}$ & $7.387 \pm 0.352^{h}$ & $13.107 \pm 0.122^{b}$ & $11.880 \pm 0.180$ de \\
\hline 7. Fludioxonil + fluxapyroxad + triticonazole & $11.307 \pm 0.124^{\mathrm{a}}$ & $8.197 \pm 0.196^{\mathrm{fg}}$ & $12.527 \pm 0.072^{c}$ & $11.553 \pm 0.278^{\mathrm{e}}$ \\
\hline 8. Fludioxonil & $6.560 \pm 0.110^{j}$ & $7.570 \pm 0.208^{h}$ & $9.623 \pm 0.035^{h}$ & $10.640 \pm 0.288 \mathrm{~g}$ \\
\hline LSD & \multicolumn{2}{|c|}{0.454} & \multicolumn{2}{|c|}{0.350} \\
\hline
\end{tabular}

Table 4. The influence of the seed treatment and drought stress on transpiration rate $-\mathrm{E}\left(\mathrm{mmol} \times \mathrm{m}^{-2} \times \mathrm{s}^{-1}\right)$ during drought stress and after regeneration.

\begin{tabular}{|c|c|c|c|c|}
\hline \multirow{2}{*}{ Treatment } & \multicolumn{2}{|c|}{ During Drought Stress } & \multicolumn{2}{|c|}{ After Regeneration } \\
\hline & Control & Drought & Control & Drought \\
\hline 1. Control - untreated & $1.903 \pm 0.046^{\mathrm{e}}$ & $1.550 \pm 0.010^{f}$ & $1.990 \pm 0.010^{j}$ & $3.020 \pm 0.010 \mathrm{gh}$ \\
\hline 2. Fludioxonil & $2.205 \pm 0.085^{d}$ & $1.523 \pm 0.040^{\mathrm{f}}$ & $2.567 \pm 0.227^{\mathrm{i}}$ & $3.217 \pm 0.091 \mathrm{fg}$ \\
\hline 3. Fludioxonil + sedaxane & $2.717 \pm 0.115^{b}$ & $1.350 \pm 0.040 \mathrm{gh}$ & $3.793 \pm 0.114^{\mathrm{a}}$ & $3.673 \pm 0.051 \mathrm{ab}$ \\
\hline 4. Fludioxonil + sedaxane + triticonazole & $3.110 \pm 0.040^{\mathrm{a}}$ & $1.463 \pm 0.105 \mathrm{fg}$ & $3.403 \pm 0.086^{\text {cdef }}$ & $3.617 \pm 0.110^{a b c}$ \\
\hline 5. Triticonazole & $1.983 \pm 0.178^{\mathrm{e}}$ & $1.523 \pm 0.143^{\mathrm{f}}$ & $2.923 \pm 0.118^{h}$ & $3.523 \pm 0.021 \mathrm{bcd}$ \\
\hline 6. Prothioconazole + tebuconazole & $2.190 \pm 0.085^{\mathrm{d}}$ & $1.953 \pm 0.064^{\mathrm{e}}$ & $3.247 \pm 0.168^{\text {efg }}$ & $3.370 \pm 0.392$ cdef \\
\hline 7. Fludioxonil + fluxapyroxad + triticonazole & $2.523 \pm 0.131^{\mathrm{c}}$ & $1.280 \pm 0.066^{\mathrm{h}}$ & $3.013 \pm 0.038 \mathrm{gh}$ & $3.493 \pm 0.095$ bcde \\
\hline 8. Fludioxonil & $2.110 \pm 0.098^{d}$ & $1.390 \pm 0.066^{\mathrm{fgh}}$ & $2.497 \pm 0.129^{\mathrm{i}}$ & $3.347 \pm 0.093$ def \\
\hline LSD & \multicolumn{2}{|c|}{0.166} & \multicolumn{2}{|c|}{0.256} \\
\hline
\end{tabular}

${ }^{a-h}$ different letters indicate statistically different mean values $p<0.0001$. 
Table 5. The influence of the seed treatment and drought stress on stomatal conductance $-\mathrm{Gs}\left(\mathrm{mol} \times \mathrm{m}^{-2} \times \mathrm{s}^{-1}\right)$ during drought stress and after regeneration.

\begin{tabular}{|c|c|c|c|c|}
\hline \multirow{2}{*}{ Treatment } & \multicolumn{2}{|c|}{ During Drought Stress } & \multicolumn{2}{|c|}{ After Regeneration } \\
\hline & Control & Drought & Control & Drought \\
\hline 1. Control - untreated & $0.100 \pm 0.001$ de & $0.067 \pm 0.006 \mathrm{gh}$ & $0.130 \pm 0.010 \mathrm{~g}$ & $0.180 \pm 0.010^{\mathrm{e}}$ \\
\hline 2. Fludioxonil & $0.130 \pm 0.010^{b c}$ & $0.073 \pm 0.006^{\text {fgh }}$ & $0.157 \pm 0.015^{f}$ & $0.193 \pm 0.015^{\mathrm{e}}$ \\
\hline 3. Fludioxonil + sedaxane & $0.170 \pm 0.020^{\mathrm{a}}$ & $0.083 \pm 0.006^{\text {efg }}$ & $0.267 \pm 0.015^{\mathrm{a}}$ & $0.227 \pm 0.006^{b c}$ \\
\hline 4. Fludioxonil + sedaxane + triticonazole & $0.167 \pm 0.021^{\mathrm{a}}$ & $0.087 \pm 0.006^{\mathrm{ef}}$ & $0.243 \pm 0.006^{b}$ & $0.223 \pm 0.015^{c}$ \\
\hline 5. Triticonazole & $0.110 \pm 0.010^{\mathrm{d}}$ & $0.070 \pm 0.001 \mathrm{fgh}$ & $0.217 \pm 0.006^{c}$ & $0.193 \pm 0.006^{\mathrm{e}}$ \\
\hline 6. Prothioconazole + tebuconazole & $0.140 \pm 0.010^{b}$ & $0.077 \pm 0.006^{\text {fgh }}$ & $0.213 \pm 0.006^{\mathrm{cd}}$ & $0.196 \pm 0.004 \mathrm{de}$ \\
\hline 7. Fludioxonil + fluxapyroxad + triticonazole & $0.163 \pm 0.015^{\mathrm{a}}$ & $0.077 \pm 0.006^{\text {fgh }}$ & $0.233 \pm 0.006^{b}$ & $0.227 \pm 0.012 b c$ \\
\hline 8. Fludioxonil & $0.117 \pm 0.015^{\mathrm{cd}}$ & $0.063 \pm 0.006^{\mathrm{h}}$ & $0.147 \pm 0.015^{\mathrm{fg}}$ & $0.197 \pm 0.006^{\mathrm{de}}$ \\
\hline
\end{tabular}

a-h different letters indicate statistically different mean values; for measurement during drought stress $p<0.0003$, for measurement after regeneration $p<0.0001$.

Table 6. The influence of the seed treatment and drought stress on sub-stomatal $\mathrm{CO}_{2}-\mathrm{Ci}\left(\mu \mathrm{mol} \times \mathrm{mol}^{-1}\right)$ during drought stress and after regeneration.

\begin{tabular}{|c|c|c|c|c|}
\hline \multirow{2}{*}{ Treatment } & \multicolumn{2}{|c|}{ During Drought Stress } & \multicolumn{2}{|c|}{ After Regeneration } \\
\hline & Control & Drought & Control & Drought \\
\hline 1. Control-untreated & $212.7 \pm 3.786^{f}$ & $171.0 \pm 4.583^{\mathrm{i}}$ & $221.7 \pm 2.517^{\mathrm{h}}$ & $228.0 \pm 8.660 \mathrm{gh}$ \\
\hline 2. Fludioxonil & $242.3 \pm 9.019 \mathrm{bc}$ & $188.3 \pm 3.055 \mathrm{gh}$ & $236.7 \pm 1.528 \mathrm{fg}$ & $238.0 \pm 1.000^{\mathrm{f}}$ \\
\hline 3. Fludioxonil + sedaxane & $253.0 \pm 4.359 \mathrm{ab}$ & $196.7 \pm 6.658^{g}$ & $262.3 \pm 3.512^{\mathrm{a}}$ & $247.6 \pm 7.767$ cde \\
\hline 4. Fludioxonil + sedaxane + triticonazole & $256.0 \pm 5.000^{\mathrm{a}}$ & $196.7 \pm 5.686^{g}$ & $260.0 \pm 4.359 \mathrm{ab}$ & $252.0 \pm 2.646^{\mathrm{bcd}}$ \\
\hline 5. Triticonazole & $220.7 \pm 10.017$ ef & $179.0 \pm 2.646^{\mathrm{hi}}$ & $239.0 \pm 2.646^{\text {ef }}$ & $239.3 \pm 2.082$ ef \\
\hline 6. Prothioconazole + tebuconazole & $232.3 \pm 10.970^{\mathrm{cd}}$ & $193.7 \pm 9.292 \mathrm{~g}$ & $237.3 \pm 12.423^{f}$ & $238.6 \pm 1.155^{\mathrm{f}}$ \\
\hline 7. Fludioxonil + fluxapyroxad + triticonazole & $245.3 \pm 4.509^{a b}$ & $190.3 \pm 3.512 \mathrm{gh}$ & $253.0 \pm 0.000 \mathrm{bc}$ & $243.7 \pm 3.215^{\text {def }}$ \\
\hline 8. Fludioxonil & $230.0 \pm 4.582^{\mathrm{de}}$ & $170.0 \pm 7.810^{\mathrm{i}}$ & $237.0 \pm 5.568^{f}$ & $237.7 \pm 2.309^{f}$ \\
\hline LSD & \multicolumn{2}{|c|}{11.628} & \multicolumn{2}{|c|}{8.915} \\
\hline
\end{tabular}

$\overline{\text { a-i }}$ different letters indicate statistically different mean values; for measurement during drought stress $p<0.026$, for measurement after regeneration $p<0.015$ 


\subsection{Effect of the Seed Treatments on the Physiological State of Plants after After Regeneration}

The assessment of the physiological state of plants at regeneration, after previously imposed drought stress, was carried out analogously to that under that same stress. Photosynthetic activity and chlorophyll fluorescence were measured.

A significant influence of the applied seed treatments on the efficiency of photosynthesis measured after plant regeneration was observed. The highest values of parameter A were found for plants with seeds subjected to treatment No. 4, which had also been subjected to drought stress (exceeding the untreated drought-stressed control by $31 \%$ ) and for plants with seeds subjected to treatment No. 3 , growing under well-watered conditions (exceeding untreated the unstressed control by more than 43\%) (Table 2). The highest values of the parameters E, Gs, and Ci were found in plants previously growing under well-watered conditions, for which seed treatment No. 3 was used, and the increase in their values in relation to the untreated unstressed control was $91 \%, 105 \%$, and $18 \%$, respectively. Among plants previously subjected to drought stress, the highest level of transpiration was recorded for plants with seeds subjected to treatment No. 3 (higher than untreated by 22\%) (Table 3), the highest stomata conductivity in plants with seeds subjected to treatments No. 3 and 7 (higher than untreated by $26 \%$ ) (Table 4), whereas the highest concentration of sub-stomatal $\mathrm{CO}_{2}$ concentration in plants with seeds subjected to treatment No. 4 (higher than untreated by $11 \%$ ) (Table 5). The lowest values of transpiration and sub-stomatal concentration of $\mathrm{CO}_{2}$ after previous drought stress were recorded for the untreated plants, and stomatal conductance additionally in plants with seeds subjected to treatments No. 2 and 5.

Measurement of chlorophyll fluorescence after regeneration indicated that majority of the seed treatments used had a positive effect on the photosystem II regeneration process. The differences for the measured fluorescence parameters values of the plants growing under well-watered conditions and the plants with their seeds treated with any treatment were smaller than these for the respective measurements under drought. Notably, no such effect was found for plants with seeds subjected to treatment No. 8.

Similar to the measurements under drought, the highest values of the $\mathrm{F}_{0}$ parameter after regeneration were noted for the untreated plants (Figure 1), followed by the plants with seeds subjected to treatments No. 2, 8, 5, and 6, and the lowest in plants with seeds subjected to treatment No. 3. Measurement of the $F_{m}$ parameter indicated the highest maximum fluorescence values in the group of plants subjected to drought stress with seeds subjected to treatments No. 3 and 7 (higher than the non-treated by $15 \%$ ), and the lowest in the plants with seeds subjected to treatment No. 8 . Analysis of fluorescence-related parameters after regeneration indicated the largest Quantum Yield of Photosynthetic Energy (Y) and Electron Transport Rate (ETR) in plants with seeds subjected to treatments No. 3, 4, and 7 in both drought-stressed plants and those under well-watered conditions. The values of the parameter $Y$ in plants subjected to drought stress with seeds subjected to treatments No. 7 and 4 exceeded those of the untreated plants by $94 \%$ and $92 \%$, respectively, whereas the ETR parameter by $95 \%$ and $92 \%$, respectively. Notably, plants with seeds subjected to treatments No. 3, 4, and 7 and stressed with drought have shown a higher Quantum Yield of Photosynthetic Energy and Electron Transport Rate than plants not previously stressed, with seeds subjected to treatments with other treatments. The lowest values of both fluorescence parameters were found in plants with seeds subjected to treatment No. 8 and untreated control.

\subsection{Principal Component Analysis}

To assess the relationship between the analyzed parameters of the physiological state of plants (Ci; Gs; A; E; Y; $\mathrm{F}_{0} ; \mathrm{F}_{\mathrm{m}} ; \mathrm{ETR}$ ) and the seed treatments used (1-8), under drought (Figure 2A) and after plant regeneration (Figure 2B), an analysis of the main principal components (PCA) was carried out. Such analysis allows to determine the variables that have the greatest impact on the individual major components. It also facilitates the interpretation of the impact of the seed treatment used on barley tolerance to drought, which in turn may have an impact on the yield. Each of the vectors represents one 
variable, and their sizes and directions describe the effect they exert on the main components. Based on this analysis, plants treated with seed treatments from the SDHI group (No. 3, 4, and 7) showed significantly higher tolerance to drought. In addition, after the stress factor has ceased (after apply watering), the plants returned faster to better physiological conditions.
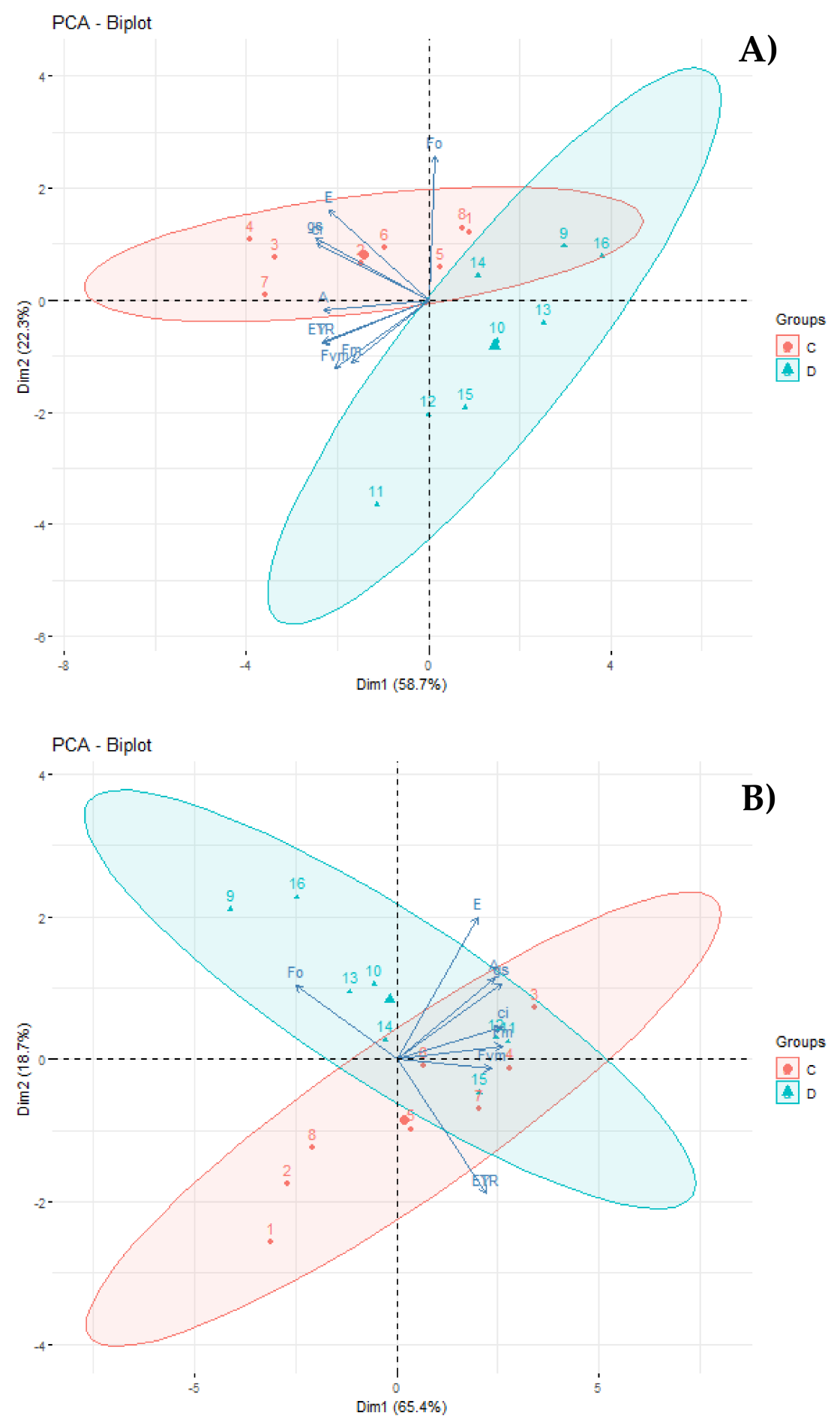

Figure 2. Projection of the variables on the component plane $(1 \times 2)$ : $(\mathbf{A})$-during drought stress; (B)—after plant regeneration. C: control; D: drought stress; 1-8: seed treatments (well-watered); 9-16: seed treatments (drought stress); Dim: dimension. 


\section{Discussion}

Seed treatments may affect many aspects of plant growth and development. In the case of triazoles, literature data indicate one negative impact - inhibition of growth in roots and plant seedlings. This is especially true for two substances: triadimefon and triadimenol [8]. Delay in primary leaf elongation is another negative effect noted in several crops after application of triazoles as seed treatment [9]. In the case of triadimenol and triticonazole, available experimental evidence points to the reducing effect of the length of coleoptiles, first leaves, and first internodes in wheat seedlings [3,12]. Triazoles, i.e., prothioconazole, tebuconazole, and triticonazole, were also tested as seed treatments in this study. Prothioconazole and tebuconazole in its composition (No. 6) had the biggest impact on the reduction of seedling growth, but the lowest vigor index was also observed. Seed treatments with the most stimulating effect on barley seedlings contained sedaxane and fluxapyroxad, and that effect was particularly evident in the root length analysis. Longer roots can take up more water, which helps mitigate the drought in critical plant growth stages and results in higher harvest rates and reduced water loss under drought [48]. During drought, the roots signal to the leaves, to reduce the transpiration and growth rate, while increasing the efficiency of water consumption [49]. Efficient or larger root systems contribute to adaptation in dry environments, particularly when plants rely on seasonal rainfall, but they are less effective in the environments where crop growth depends on the surface soil water [50]. Therefore, a well-developed root system in the early stages of plant development is extremely important. Carefully chosen seed treatment can be helpful in ensuring that.

Facing the climate change, one possible way to increase barley yield under adverse climatic conditions is to improve the plant photosynthetic efficiency [51]. Modern, non-invasive measuring instruments that conduct measurements based on the difference in the concentration of $\mathrm{CO}_{2}$ and $\mathrm{H}_{2} \mathrm{O}$ in the air and the amount of air flowing through the plant material in a unit of time, allow to assess the degree of $\mathrm{CO}_{2}$ assimilation and transpiration. Particularly valuable results in assessing the physiological state of plants under the abiotic stress and after regeneration can be obtained as a result of combining gas exchange assessment with chlorophyll fluorescence testing [52]. Experiments conducted on many crop species indicated the possibility of a wide application of chlorophyll fluorescence parameters in the detection of metabolic disorders also caused by plant protection products [53]. According to Berdugo et al. [54] the decrease in photosynthetic activity in the aging leaves is associated with the reduction of photochemical reactions happening in the PSI and PSII, therefore the use of chlorophyll fluorescence is an accurate method for detecting changes in the physiological state of plant tissue resultant from fungicide application. Our results lead to similar conclusions. The values of winter barley chlorophyll fluorescence indices, such as $\mathrm{F}_{0}, \mathrm{~F}_{\mathrm{m}}, \mathrm{Y}$, and ETR, depended on the type of seed treatment used. The use of treatments, especially those containing sedaxane and fluxapyroxad, had a positive effect on mitigating the damage to the photosynthetic apparatus caused by drought. This stress is considered one of the most important environmental factors limiting growth, plant metabolism, and crop productivity around the world [55-57]. Photosystem II (PSII) is the most important protein-pigment complex in chloroplasts, but also the most susceptible to drought [32]. Minimal fluorescence (parameter $\mathrm{F}_{0}$ ) of dark-adapted leaf is an indicator of the excitation energy loss during its transfer energy to the PSII reaction center [58]. Higher values of that parameter due to drought stress in the untreated plants may indicate their lower efficiency of the excitation energy transfer between photosynthetic complexes. We recorded the highest values of the $\mathrm{F}_{0}$ parameter in the untreated plants, both under drought stress and unstressed, and the lowest in treated plants with seeds subjected to treatments No. 3, 4, and 7 subjected to drought stress. After plant regeneration, the highest value of the $\mathrm{F}_{0}$ parameter measured was found in the untreated plants previously exposed to drought stress, whereas the lowest value in plants with seeds subjected to treatment No. 3. The $\mathrm{F}_{\mathrm{m}}$ parameter, dependent among others on the chlorophyll contents in plant tissue, indicates the maximum fluorescence intensity of plants adapted to darkness, and the reduced values of this indicator can be caused by damage that prevents the total reduction of electron acceptors in PSII. Daszkowska-Golec et al. [51] observed in their studies of barley photosynthesis that the value 
of the $F_{m}$ parameter decreased significantly as a result of drought only as a result of prolonged stress. In our studies, the lowest values of $\mathrm{F}_{\mathrm{m}}$ under drought were recorded for untreated plants subjected to drought, whereas the most favorable values were recorded for plants subjected to drought with seeds subjected to treatment No. 3. Plants with seeds subjected to treatments No. 3, 7, and 4 (all of the tested preparations containing active substances from the SDHI group) showed the highest values of the $F_{m}$ parameter after regeneration, whereas the lowest values were found for plants stressed by drought with seeds subjected to treatment No. 8 .

Significant differences were also shown for two photosynthesis-related parameters measured under the light: $Y$ and ETR. The Y parameter specifies the ratio of the quantum used in photochemical transformations to the total number of PAR quanta absorbed [59], whereas the ETR parameter is the product of the value of $\mathrm{Y}$ and the value of light photons during the measurement multiplied by 0.5 (to transport 1 electron by both photocircuits, they need the absorption of 2 PAR quanta). Here, under drought, the highest ETR value, and thus the highest quantum yield of photochemical reactions in PSII, was shown by the unstressed plants with seeds subjected to treatments No. 7, 3, and 4. In these plants, however, a decrease in the value of both parameters was noted as a result of drought stress. This can be considered an indicator of the physiological regulation of electron transport by increased quenching of excitation energy in the PSII antennas [60]. This assumption was confirmed by the results of both parameters measured after regeneration, when the highest values of both parameters were recorded for the previously unstressed plants, followed by drought stress treated plants with the same active substances from the SDHI group (isopyrazam). In the research of Ajigboye et al. [61], with sprays using three fungicide preparations in winter wheat plants, under drought the application of substances from the SDHI group resulted in a significant increase of the maximum photochemical efficiency of PSII and the speed of electron transport. In their subsequent studies, Ajigboye et al. [22] have shown that the sedaxane used as seed treatment caused a significant increase in the efficiency of excitation energy capture by open PSII reaction centers in plants exposed to drought stress. This is in line with another study [54], which showed an increase in the effective quantum yield of PSII under drought compared to the untreated control at a significant level only in the group of plants treated with a substance from the SDHI group (bifaxene).

Analysis of gene expression and measurements of chlorophyll fluorescence and gas exchange showed that fungicides from the group of SDHI increase photosynthesis and PSII efficiency in wheat plants under drought stress conditions [22]. Sedaxane used as seed treatment for wheat grain later cultivated under drought redirected the metabolites from stress defense reactions to plant adaptation processes. This has now been confirmed in our research on barley; here the gas exchange in plants stressed by drought and growing under well-watered conditions was also measured, both under imposed drought and after regeneration. Plants treated with substances from the SDHI group reduced water transpiration under drought stress conditions, with the lowest values of parameter E recorded for such treatments. But, high values of transpiration after regeneration indicate that the reduction of water evaporation was the result of a defense mechanism against excessive water loss. Drought tolerance is the ability to maintain a relatively high carboxylation to maintain high photosynthesis efficiency [30]. In response to abiotic stress, such as unfavorable temperature, humidity, light intensity, or $\mathrm{CO}_{2}$ concentration in the atmosphere, plants regulate the number of stomata in the developing leaves. Owing to this specific adaptation, plants can minimize the water loss and optimize $\mathrm{CO}_{2}$ assimilation, thereby increasing their water use efficiency [62]. Assessment of the photosynthetic activity in soybeans growing 7 days under drought showed a decrease in $\mathrm{CO}_{2}$ assimilation in the stressed plants compared to unstressed plants by $25 \%$, transpiration by $48 \%$, stomatal conductance by $66 \%$, sub-stomatal $\mathrm{CO}_{2}$ conductance (Ci) by $26 \%$ [63]. Daszkowska-Golec et al. [51] in their studies on barley photosynthesis noted a significant quadruple decrease in the Gs parameter value at the first stage of drought, which decreased three times more as result of the stress prolonged for the next 10 days. Notably, among the analyzed plants under drought, the highest values of $\mathrm{Ci}$ and Gs parameters were also shown for plants treated with substances from the SDHI group. In addition, 
measurements after regeneration showed the highest $\mathrm{Ci}$ and $\mathrm{Gs}$ values for non-stressed plants with seeds subjected to treatments No. 3, 4, and 7, but also for those that were previously under drought stress treated with the same substances. Winter wheat sprayed with three fungicide preparations from the SDHI group (isopyrazam) exhibited comparable values of the photosynthesis intensity and chlorophyll fluorescence under drought, the highest values of $\mathrm{CO}_{2}$ assimilation, transpiration, stomatal conductivity, and PSII efficiency [61]. Contrastingly, in our studies there was a significant reduction in transpiration under drought in plants with seeds subjected to treatments with the SDHI group agents, with comparatively high values of the other parameters-A, Ci and Gs. Inhibition of the SDH activity by partial reduction of SDH subunits has been shown in tomatoes and Arabidopsis as an action to increase the photosynthetic efficiency of leaves by increasing stomatal conductance $[64,65]$. Other studies that observed an improvement in photosynthesis and an increase in biomass in wheat seedlings treated with sedaxane, suggested that it may have contributed to maintaining the function of stomata under drought [22].

\section{Conclusions}

The seed treatments tested here differed significantly in their impacts on the vigor parameters of the barley grain, as well as on the physiological state of seedlings under drought and after regeneration. Seed treatments based on the substances from the SDHI group (sedaxane and fluxapyroxad) did not cause inhibition of seedling growth, which was also confirmed by the highest values of the vigor index. Substances from the triazole group have showed inhibition of seedling growth in other studies. With regards to the analysis of photosynthesis-related parameters, seed treatments from the SDHI group contributed to a comparably better tolerance of the imposed drought in spring barley. The above preparations, in addition to protection against abiotic stress, also rendered a higher efficiency of photochemical reactions in the treated plants. These preliminary analysis results indicate the possibility of using substances from the SDHI group to reduce drought stress in plants, however further studies on their activities could improve our knowledge about the mechanisms underlying the beneficial effects observed in the current experiments.

Author Contributions: Conceptualization, D.R. and Z.S.; Data curation, R.G.-W.; Formal analysis, D.R., P.E.K., R.G.-W. and M.N.; Investigation, D.R., M.G., P.E.K. and Z.S.; Methodology, D.R. and Z.S.; Software, R.G.-W.; Supervision, D.R.; Writing-original draft, D.R., M.G., P.Ł.K., A.B., R.G.-W., M.N. and Z.S.; Writing-review \& editing, D.R., P.E.K., M.N. and Z.S. All authors have read and agreed to the published version of the manuscript.

Funding: This research received no external funding.

Acknowledgments: The paper was financed within the framework of Ministry of Science and Higher Education programme 'Regional Initiative of Excellence' in years 2019-2022, Project No. 005/RID/2018/19.

Conflicts of Interest: The authors declare no conflict of interest.

\section{References}

1. Görtz, A.; Oerke, E.-C.; Puhl, T.; Steiner, U. Effect of environmental conditions on plant growth regulator activity of fungicidal seed treatments of barley. J. Appl. Bot. Food Qual. 2008, 82, 60-68.

2. Kumar, S. Cultural Approaches for Plant Disease Management. Res. Rev. J. Agric. Sci. Technol. 2012, 1, 12-21.

3. Montfort, F.; Klepper, B.L.; Smiley, R.W. Effects of Two Triazole Seed Treatments, Triticonazole and Triadimenol, on Growth and Development of Wheat. Pestic. Sci. 1996, 46, 315-322. [CrossRef]

4. Sawinska, Z. The influence of seed treatment efficacy against leaf diseases in spring barley. Prog. Plant Prot. 2008, 48, 516-519.

5. Sawinska, Z.; Khachatryan, K.; Sobiech, Ł.; Idziak, R.; Kosiada, T.; Skrzypczak, G.; Sobiech, L.; Idziak, R.; Kosiada, T.; Skrzypczak, G. Use of silver nanoparticles as a fungicide. Przem. Chem. 2014, 93, 1472-1474. [CrossRef]

6. Deliopoulos, T.; Kettlewell, P.S.; Hare, M.C. Fungal disease suppression by inorganic salts: A review. Crop Prot. 2010, 29, 1059-1075. [CrossRef] 
7. Kuck, K.H.; Scheinpflug, H.; Pontzen, R. DMI fungicides. In Modern Selective Fungicides Properties, Applications, Mechanisms of Action; Lyr, H., Ed.; Gustav Fischer Verlag: New York, NY, USA, 1995; pp. 259-290.

8. Förster, H.; Buchenauer, H.; Grossmann, F. Nebenwirkungen der systemischen Fungizide Triadimefon und Triadimenol auf Gersten-pflanzen. I. Beeinflussung von Wachstum und Ertrag. J. Plant Dis. Prot. 1980, 87, 473-492.

9. Buchenauer, H.; Kutzner, B.; Kohts, T. Effect of various triazole fungicides on growth of cereal seedlings and tomato plants as well as on gibberellin contents and lipid metabolism in barley seedlings. J. Plant Dis. Prot. 1984, 91, 506-524.

10. Buchenauer, H.; Röhner, E. Effect of triadimefon and triadimenol on growth of various plant species as well as on gibberellin content and sterol metabolism in shoots of barley seedlings. Pestic. Biochem. Physiol. 1981, 15, 58-70. [CrossRef]

11. Anderson, H.M. Effect of triadimenol seed treatment on vegetative growth in winter wheat. Crop Res. 1989, 29, 29-36.

12. Cavariani, C.; Velini, E.D.; Bicudo, S.J.; Nakagawa, J. Avaliação dos efeitos de doses de triadimenol e de tebuconazole sobre o crescimento do mesocótilo em plântulas de trigo. Pesq. Agropec. Bras. 1999, 29, 1035-1039.

13. Avenot, H.; Morgan, D.P.; Michailides, T.J. Resistance to pyraclostrobin, boscalid and multiple resistance to Pristine ${ }^{\circledR}$ (pyraclostrobin + boscalid) fungicide in Alternaria alternata causing alternaria late blight of pistachios in California. Plant Pathol. 2008, 57, 135-140. [CrossRef]

14. Kuhn, P.J. Mode of action of carboximides. In British Mycological Society Symposia Series; Elsevier: Amsterdam, The Netherlands, 1984; pp. 155-183.

15. Stammler, G.; Brix, H.D.; Glattli, A.; Semar, M.; Schoefl, U. Biological properties of the carboxamide boscalid including recent studies on its mode of action. In Proceedings of the XVI Intonational Plant Protection Congress, Glasgow, KY, USA, 15-18 October 2007; pp. 40-45.

16. Zhang, C.Q.; Liu, Y.H.; Ma, X.Y.; Feng, Z.; Ma, Z.H. Characterization of sensitivity of Rhizoctonia solani, causing rice sheath blight, to mepronil and boscalid. Crop Prot. 2009, 28, 381-386. [CrossRef]

17. Avenot, H.F.; Michallides, T.J. Resistance to pyraclostrobin, boscalid and Pristine (pyraclostrobin plus boscalid) in Alternaria alternate isolates from California pistachio. Phytopathology 2007, 97, S5-S7.

18. Sierotzki, H.; Scalliet, G. A Review of Current Knowledge of Resistance Aspects for the Next-Generation Succinate Dehydrogenase Inhibitor Fungicides. Phytopathology 2013, 103, 880-887. [CrossRef]

19. Walter, H.; Tobler, H.; Ehrenfreund, J. O-Cyclopropyl-Carboxanilides and Their Use as Fungicides 2003. Patent EP1480955B1, 21 February 2020.

20. Rheinheimer, J. Succinate dehydrogenase inhibitors. In Modern Crop Protection Compounds; Kraemer, W., Schirmer, U., Jeschke, P., Witschel, M., Eds.; Wiley-VCH: Weinheim, Germany, 2012; pp. 627-639.

21. Zeun, R.; Scalliet, G.; Oostendorp, M. Biological activity of sedaxane-A novel broad-spectrum fungicide for seed treatment. Pest Manag. Sci. 2013, 69, 527-534. [CrossRef]

22. Ajigboye, O.O.; Lu, C.; Murchie, E.H.; Schlatter, C.; Swart, G.; Ray, R.V. Altered gene expression by sedaxane increases PSII efficiency, photosynthesis and growth and improves tolerance to drought in wheat seedlings. Pestic. Biochem. Physiol. 2017, 137, 49-61. [CrossRef]

23. Conclusion on the peer review of the pesticide risk assessment of the active substance fluxapyroxad (BAS 700 F). EFSA J. 2012, 10, 2522. [CrossRef]

24. Cavell, P.; Blanchard, J.; Coquiller, M.; Fritz-Piou, S.; Gourmelin, P.; Morvan, Y.; Cousin, A. BAS 70005 F: A new innovative fungicide solution from BASF to protect seed-, soil-borne diseases and more-Case study of barley protection. In Proceedings of the 10 Conférence Internationale sur les Maladies des Plantes, Tours, France, 3-5 December 2012; pp. 581-588.

25. Mittler, R. Abiotic stress, the field environment and stress combination. Trends Plant Sci. 2006, 11, 15-19. [CrossRef]

26. Swędrzyńska, D.; Zielewicz, W.; Swędrzyński, A. Comparison of soil bioconditioners and standard fertilization in terms of the impact on yield and vitality of Lolium perenne and soil biological properties. Open Life Sci. 2019, 14, 666-680. [CrossRef]

27. Bandurska, H.; Niedziela, J.; Pietrowska-Borek, M.; Nuc, K.; Chadzinikolau, T.; Radzikowska, D. Regulation of proline biosynthesis and resistance to drought stress in two barley (Hordeum vulgare L.) genotypes of different origin. Plant Physiol. Biochem. 2017, 118, 427-437. [CrossRef] [PubMed] 
28. Weraduwage, S.M.; Chen, J.; Anozie, F.C.; Morales, A.; Weise, S.E.; Sharkey, T.D. The relationship between leaf area growth and biomass accumulation in Arabidopsis thaliana. Front. Plant Sci. 2015, 6. [CrossRef] [PubMed]

29. Gonzalez-Mendoza, D.; Valdez-Salas, B.; Bernardo-Mazariegos, E.; Tzintzun-Camacho, O.; Gutiérrez-Miceli, F.; Ruíz-Valdiviezo, V.; Rodríguez-Hernández, L.; Sanchez-Viveros, G. Influence of monometallic and bimetallic phytonanoparticles on physiological status of mezquite. Open Life Sci. 2019, 14, 62-68. [CrossRef]

30. Gupta, A.; Rico-Medina, A.; Caño-Delgado, A.I. The physiology of plant responses to drought. Science (80-.) 2020, 368, 266-269. [CrossRef] [PubMed]

31. Maxwell, K.; Johnson, G.N. Chlorophyll fluorescence-A practical guide. J. Exp. Bot. 2000, 51, 659-668. [CrossRef]

32. Baker, N.R. Chlorophyll Fluorescence: A Probe of Photosynthesis In Vivo. Annu. Rev. Plant Biol. 2008, 59, 89-113. [CrossRef] [PubMed]

33. Bolhàr-Nordenkampf, H.R.; Öquist, G. Chlorophyll fluorescence as a tool in photosynthesis research. In Photosynthesis and Production in a Changing Environment; Springer: Dordrecht, The Netherlands, 1993; pp. 193-206.

34. Waqas, M.A.; Kaya, C.; Riaz, A.; Farooq, M.; Nawaz, I.; Wilkes, A.; Li, Y. Potential Mechanisms of Abiotic Stress Tolerance in Crop Plants Induced by Thiourea. Front. Plant Sci. 2019, 10. [CrossRef]

35. Munné-Bosch, S.; Alegre, L. Cross-stress tolerance and stress "memory" in plants: An integrated view. Environ. Exp. Bot. 2013, 94,1-2. [CrossRef]

36. Li, Y.; Ye, W.; Wang, M.; Yan, X. Climate change and drought: A risk assessment of crop-yield impacts. Clim. Res. 2009, 39, 31-46. [CrossRef]

37. Hatzig, S.V.; Nuppenau, J.-N.; Snowdon, R.J.; Schießl, S.V. Drought stress has transgenerational effects on seeds and seedlings in winter oilseed rape (Brassica napus L.). BMC Plant Biol. 2018, 18, 297. [CrossRef]

38. You, J.; Chan, Z. ROS Regulation During Abiotic Stress Responses in Crop Plants. Front. Plant Sci. $2015,6$. [CrossRef] [PubMed]

39. Ghorbanpour, M.; Mohammadi, H.; Kariman, K. Nanosilicon-based recovery of barley ( Hordeum vulgare ) plants subjected to drought stress. Environ. Sci. Nano 2020, 7, 443-461. [CrossRef]

40. Kobus-Cisowska, J.; Szulc, P.; Szczepaniak, O.; Dziedziński, M.; Szymanowska, D.; Szymandera-Buszka, K.; Goryńska-Goldmann, E.; Gazdecki, M.; Telichowska, A.; Ligaj, M. Variability of Hordeum vulgare L. Cultivars in Yield, Antioxidant Potential, and Cholinesterase Inhibitory Activity. Sustainability 2020, 12, 1938. [CrossRef]

41. Hellal, F.A.; El-Shabrawi, H.M.; Abd El-Hady, M.; Khatab, I.A.; El-Sayed, S.A.A.; Abdelly, C. Influence of PEG induced drought stress on molecular and biochemical constituents and seedling growth of Egyptian barley cultivars. J. Genet. Eng. Biotechnol. 2018, 16, 203-212. [CrossRef]

42. Ceccarelli, S.; Grando, S.; Baum, M. Participatory plant breeding in water-limited environments. Exp. Agric. 2007, 43, 411-435. [CrossRef]

43. Nosalewicz, A.; Siecińska, J.; Śmiech, M.; Nosalewicz, M.; Wiącek, D.; Pecio, A.; Wach, D. Transgenerational effects of temporal drought stress on spring barley morphology and functioning. Environ. Exp. Bot. 2016, 131, 120-127. [CrossRef]

44. Dąbrowska, B.; Pokojska, H.; Suchorska-Tropiło, T. Metody Laboratoryjnej Oceny Materiału Siewnego; Wydawnictwo SGGW: Warsaw, Poland, 2000.

45. ISTA. 2011. Available online: https://www.seedtest.org/en/technical-committees-documents-_content--\$-\$1-3496.html (accessed on 20 April 2020).

46. Kowalczewski, P.Ł.; Radzikowska, D.; Ivanišová, E.; Szwengiel, A.; Kačániová, M.; Sawinska, Z. Influence of Abiotic Stress Factors on the Antioxidant Properties and Polyphenols Profile Composition of Green Barley (Hordeum vulgare L.). Int. J. Mol. Sci. 2020, 21, 397. [CrossRef]

47. Michael, G. Biplots in Practice; Books; Fundacion BBVA/BBVA Foundation: Bilbao, Spain, 2010.

48. Ludlow, M.M.; Muchow, R.C. A Critical Evaluation of Traits for Improving Crop Yields in Water-Limited Environments. Adv. Agron. 1990, 43, 107-153.

49. Reynolds, M.P.; Mujeeb-Kazi, A.; Sawkins, M. Prospects for utilising plant-adaptive mechanisms to improve wheat and other crops in drought- and salinity-prone environments. Ann. Appl. Biol. 2005, 146, 239-259. [CrossRef] 
50. Palta, J.A.; Chen, X.; Milroy, S.P.; Rebetzke, G.J.; Dreccer, M.F.; Watt, M. Large root systems: Are they useful in adapting wheat to dry environments? Funct. Plant Biol. 2011, 38, 347. [CrossRef]

51. Daszkowska-Golec, A.; Collin, A.; Sitko, K.; Janiak, A.; Kalaji, H.M.; Szarejko, I. Genetic and Physiological Dissection of Photosynthesis in Barley Exposed to Drought Stress. Int. J. Mol. Sci. 2019, 20, 6341. [CrossRef] [PubMed]

52. Witkowska-Banaszczak, E.; Radzikowska, D.; Ratajczak, K. Chemical profile and antioxidant activity of Trollius europaeus under the influence of feeding aphids. Open Life Sci. 2018, 13, 312-318. [CrossRef]

53. Habash, D.; Percival, M.P.; Baker, N.R. Rapid chlorophyll fluorescence technique for the study of penetration of photosynthetically active herbicides into leaf tissue. Weed Res. 1985, 25, 389-395. [CrossRef]

54. Berdugo, C.A.; Mahlein, A.K.; Steiner, U.; Oerke, E.C.; Dehne, H.W. Use of non-invasive sensors to detect beneficial effects of fungicides on wheat physiology. In Proceedings of the 11th International Conference on Precision Agriculture (ICPA), Indianapolis, IN, USA, 15-18 July 2012.

55. Matiu, M.; Ankerst, D.P.; Menzel, A. Interactions between temperature and drought in global and regional crop yield variability during 1961-2014. PLoS ONE 2017, 12, e0178339. [CrossRef] [PubMed]

56. Zhang, T.; Hu, F.; Ma, L. Phosphate-solubilizing bacteria from safflower rhizosphere and their effect on seedling growth. Open Life Sci. 2019, 14, 246-254. [CrossRef]

57. Boyer, J.S. Plant Productivity and Environment. Science 1982, 218, 443-448. [CrossRef]

58. Baker, N.R. Applications of chlorophyll fluorescence can improve crop production strategies: An examination of future possibilities. J. Exp. Bot. 2004, 55, 1607-1621. [CrossRef]

59. Genty, B.; Briantais, J.-M.; Baker, N.R. The relationship between the quantum yield of photosynthetic electron transport and quenching of chlorophyll fluorescence. Biochim. Biophys. Acta Gen. Subj. 1989, 990, 87-92. [CrossRef]

60. Zlatev, Z. Drought-Induced Changes in Chlorophyll Fluorescence of Young Wheat Plants. Biotechnol. Biotechnol. Equip. 2009, 23, 438-441. [CrossRef]

61. Ajigboye, O.O.; Murchie, E.; Ray, R.V. Foliar application of isopyrazam and epoxiconazole improves photosystem II efficiency, biomass and yield in winter wheat. Pestic. Biochem. Physiol. 2014, 114, 52-60. [CrossRef]

62. Ruggiero, A.; Punzo, P.; Landi, S.; Costa, A.; Van Oosten, M.; Grillo, S. Improving Plant Water Use Efficiency through Molecular Genetics. Horticulturae 2017, 3, 31. [CrossRef]

63. Ohashi, Y.; Nakayama, N.; Saneoka, H.; Fujita, K. Effects of drought stress on photosynthetic gas exchange, chlorophyll fluorescence and stem diameter of soybean plants. Biol. Plant. 2006, 50, 138-141. [CrossRef]

64. Araújo, W.L.; Nunes-Nesi, A.; Osorio, S.; Usadel, B.; Fuentes, D.; Nagy, R.; Balbo, I.; Lehmann, M.; Studart-Witkowski, C.; Tohge, T.; et al. Antisense Inhibition of the Iron-Sulphur Subunit of Succinate Dehydrogenase Enhances Photosynthesis and Growth in Tomato via an Organic Acid-Mediated Effect on Stomatal Aperture. Plant Cell 2011, 23, 600-627. [CrossRef] [PubMed]

65. Fuentes, D.; Meneses, M.; Nunes-Nesi, A.; Araújo, W.L.; Tapia, R.; Gómez, I.; Holuigue, L.; Gutiérrez, R.A.; Fernie, A.R.; Jordana, X. A Deficiency in the Flavoprotein of Arabidopsis Mitochondrial Complex II Results in Elevated Photosynthesis and Better Growth in Nitrogen-Limiting Conditions. Plant Physiol. 2011, 157, 1114-1127. [CrossRef]

(C) 2020 by the authors. Licensee MDPI, Basel, Switzerland. This article is an open access article distributed under the terms and conditions of the Creative Commons Attribution (CC BY) license (http://creativecommons.org/licenses/by/4.0/). 